\title{
(j)
}

\section{DAVID FOSTER WALLACE ON THE GOOD LIFE}

NATHAN BALLANTYNE AND JUSTIN TOSI

Dostoevsky wrote fiction about the stuff that's really important. He wrote fiction about identity, moral value, death, will, sexual vs. spiritual love, greed, freedom, obsession, reason, faith, suicide. And he did it without ever reducing his characters to mouthpieces or his books to tracts. His concern was always what it is to be a human being-that is, how to be an actual person, someone whose life is informed by values and principles, instead of just an especially shrewd kind of self-preserving animal.

-DAVID FOSTER WALLACE, "JOSEPH FRANK'S DOSTOEVSKY"

1)

avid Foster Wallace thought that the point of writing fiction was to explore what it is to be a human being. ${ }^{1}$ In this essay, we argue that his writings suggest a view about what philosophers would call the good life. Wallace's perspective is subtle and worthy of attention. We'll contrast what Wallace says with some popular positions from moral philosophy and contemporary culture.

Wallace said much about ethical matters even though he didn't write on them formally or systematically. How then shall we distill views from his writings? Our strategy is to present Wallace's reactions, as found in his fiction and some essays, to three positions about the good life. We will ask what Wallace would make of those 
positions and thus try to triangulate his own view by reference to them.

The first position we'll explore is sometimes called ironism. More often practiced than defended, for reasons that will be evident, ironism involves distancing oneself from everything one says or does and putting on what Wallace often calls a "mask of ennui." Ironism appeals to us, Wallace thought, because it insulates us from criticism, both from others and from ourselves. After all, if someone dismisses what she does as unimportant or even meaningless, she can hardly be criticized for valuing it too much. But such a person can be criticized for failing to value anything, and this is Wallace's response to the ironist. Wallace thinks that our lives should be about something. He underlines the value of sincere self-identification with what one does and cares about.

According to a second kind of position, what philosophers call hedonism, a good life consists in pleasure. Wallace would reject any form of hedonism, we surmise, because he doubts that pleasure could play such a fundamental role in the good life. A life of enjoyment is a life of private enjoyment, and we mangle values like friendship by explaining their value solely in terms of our pleasure. A good human life involves a richer assortment of goods than these theories capture.

On a third family of views-narrative theories, as we'll call them-a good human life is characterized by fidelity to a unified narrative. This is a systematic story about one's life, composed of a set of ends or principles according to which one lives. The story lays down the terms of success for a good life. Failing to live up to the story means failing to flourish. But Wallace's fiction is rife with characters who are unhappy at least partly because they try (and fail) to live up to their stories. Narrative theories, he thinks, turn people into spectators to, rather than participants in, their own lives. 
We conclude that Wallace sees serious flaws in these three popular views. But Wallace also suggests an attractive method for pursuing moral questions. Not unlike Wittgenstein, Wallace thought his task was to prevent people from being distracted by pseudoproblems in thinking. In Wallace's view, the point of theorizing is to solve actual human problems. But he also offers clear proposals about the content of a good life. The primary elements of the view on offer in Wallace's writing are these. A meaningful human life need not be special; it need not be characterized by commitment to values or projects that are unique, unusual, or extreme. There is value in ordinary, everyday, and even seemingly banal experiences. But is there a theory behind all this? What makes these things good for us? Where does his rejection of other theories leave him? And, according to him, are there facts of the matter about human well-being, such that someone could be mistaken about what makes her life go well? Our reading of Wallace will begin to sketch answers to these and other questions.

\section{WALLACE ON IRONISM}

In his 1993 essay "E Unibus Pluram: Television and U.S. Fiction," Wallace argues that "irony tyrannizes us." irony's recent history in America, it gained popularity as a cultural tool for exposing hypocrisy. Irony can purport to show, for example, that institutions commonly promote absurdly idealized images of themselves, that people's claims to represent the interests of others are often self-seeking ploys, and that many traditionally held values are in tension. Irony began its recent popularity as an avant-garde liberator. Later on, says Wallace, it became a culturally entrenched source of unhappiness.

What has this to do with the good life? Wallace sees the pervasiveness of irony in contemporary culture through its impact 
on television programming. The entertainment industry-one of the early targets of (ironic) postmodern cultural criticism-has hoisted irony's banner. Ironic humor became a staple of television because the market demands it. One of Wallace's examples here is late-night host David Letterman, the "archangel" of contemporary irony. In an interview Wallace remarked: "The particular kind of irony I'm talking about when Letterman comes out and says, 'What a fine crowd,' and everybody roars with laughter, came about in the 60s." ${ }^{3}$ Wallace argued that irony and self-consciousness had served crucial and valuable purposes but that "their aesthetic's absorption by U.S. commercial culture has had appalling consequences for writers and everyone else." ${ }^{4}$ Viewers enjoy ironic humor about news, gossip, and the like, we surmise, because they understand the ironic point of view, appreciate its presuppositions, regard ironic treatments of various topics as appropriate and smart. In short, viewers think ironically themselves. Or at least aspire to.

But irony is a source of unhappiness, thinks Wallace. Why? And how does irony attract us while making us unhappy? Here's an extended passage from Infinite Jest on the loneliness of teenaged Hal Incandenza:

It's of some interest that the lively arts of the millennial U.S.A. treat anhedonia and internal emptiness as hip and cool. It's maybe the vestiges of the Romantic glorification of Weltschmerz, which means world-weariness or hip ennui. Maybe it's the fact that most of the arts here are produced by world-weary and sophisticated older people and then consumed by younger people who not only consume art but study it for clues on how to be cool, hip-and keep in mind that, for kids and younger people, to be hip and cool is the same as to be admired and accepted and included and so Unalone. Forget so-called peer-pressure. It's more like peer-hunger. No? We enter a spiritual puberty where we snap to the fact that the great transcendent horror is 
loneliness, excluded encagement in the self. Once we've hit this age, we will now give or take anything, wear any mask, to fit, be part-of, not be Alone, we young. The U.S. arts are our guide to inclusion. A how-to. We are shown how to fashion masks of ennui and jaded irony at a young age where the face is fictile enough to assume the shape of whatever it wears. And then it's stuck there, the weary cynicism that saves us from gooey sentiment and unsophisticated naïveté. Sentiment equals naïveté on this continent. ${ }^{5}$

Irony is appealing, then, not only because adopting an ironic attitude lets us fit in and feel less alone. We also get to present ourselves as being savvy-knowingly bored with the sentimental banalities that others mistakenly value. The mask of ennui we present to others proves we at least aren't naïve.

Wallace goes on to explain why this ironic stance makes us unhappy:

Hal, who's empty but not dumb, theorizes privately that what passes for hip cynical transcendence of sentiment is really some kind of fear of being really human, since to be really human (at least as he conceptualizes it) is probably to be unavoidably sentimental and naïve and goo-prone and generally pathetic, is to be in some basic interior way forever infantile, some sort of not-quite-right-looking infant dragging itself anaclitically around the map, with big wet eyes and froggy-soft skin, huge skull, gooey drool. One of the really American things about Hal, probably, is the way he despises what it is he's really lonely for: this hideous internal self, incontinent of sentiment and need, that pules and writhes just under the hip empty mask, anhedonia. ${ }^{6}$

Wallace's insight on irony is this: when worn as a mask, irony helps one cast a striking figure, but it is privately, personally 
destructive. It prevents us from doing what human nature pushes us to do: to care about things sincerely and to pursue what we care about. Once in the grip of irony, we are so afraid of appearing really to value things that we turn ironic to the core. We don't value anything at all. Irony is, Wallace writes, "not a rhetorical mode that wears well. ... This is because irony, entertaining as it is, serves an almost exclusively negative function. It's critical and destructive, a ground-clearing. ... But irony's singularly unuseful when it comes to constructing anything to replace the hypocrisies it debunks."7 It leaves human beings empty and isolated, with no way to improve their situation-aside from subjecting themselves to ironic criticism.

Another observer, Richard Rorty, once set down a statement of just the sort of thing Wallace described. ${ }^{8}$ Rorty writes:

All human beings carry about a set of words which they employ to justify their actions, their beliefs, and their lives. These are the words in which we formulate praise of our friends and contempt for our enemies, our long-term projects, our deepest self-doubts and our highest hopes. They are the words in which we tell, sometimes prospectively and sometimes retrospectively, the story of our lives. I shall call these words a person's "final vocabulary."

With that terminology in hand, Rorty continues:

I shall define an "ironist" as someone who fulfills three conditions: (1) She has radical and continuing doubts about the final vocabulary she currently uses, because she has been impressed by other vocabularies, vocabularies taken as final by people or books she has encountered; (2) she realizes that argument phrased in her present vocabulary can neither underwrite nor 
dissolve these doubts; (3) insofar as she philosophizes about her situation, she does not think that her vocabulary is closer to reality than others, that it is in touch with a power not herself. ${ }^{10}$

Insofar as Rorty's ironist can be committed to valuing anything, it is only in a weak sense. The ironist seriously doubts that what she values is really important. Her commitment won't withstand criticism from anyone who rejects it. To defend against such criticism, the ironist has two options. She might shoot back at her critic, charging that he's simply foisting his values on others, as he can't defend his values from outside criticism either. Or the ironist might instead distance herself from the thing she values, confessing that it's not valuable.

But Rorty manages to stay upbeat about the ironist's stance. Rorty argues that a society of ironists can remain committed to humane values by distinguishing between public and private justification. In Rorty's society of ironists, people "would feel no more need to answer the questions 'Why are you a liberal? Why do you care about the humiliation of strangers?' than the average sixteenth-century Christian felt to answer the question 'Why are you a Christian?' "11 But ironists' private stance is another matter. They are "never quite able to take themselves seriously because [they are] always aware that the terms in which they describe themselves are subject to change, always aware of the contingency and fragility of their final vocabularies, and thus of their selves." ${ }^{12}$

It's important to see a difference between Rorty's ironist and Wallace's. The Rortean ironist is "impressed by other vocabularies" and thus seems to have some basis for her ironic intellectual stance. But Wallace's ironist isn't intellectually motivated and, if anything, goes in for ironism because of a desire to be beyond 
criticism, to be cool. Of course, these approaches to ironism aren't incompatible. Nevertheless, Wallace would not be satisfied with Rorty's positive take on ironism. How we feel about ourselves and our values matters. Hal is not leading a good life. Rorty would point out that Hal can remain publicly committed to caring about the suffering of others. But this is of no consolation to Hal. His private emptiness is a form of suffering, too.

Though irony once had a purpose, Wallace thinks, it became a source of the kind of cruelty it earlier undermined. Wallace's speculation on possible means of irony's removal offers further insight into his views about the good life:

The next real literary "rebels" in this country might well emerge as some weird bunch of anti-rebels, born oglers who dare somehow to back away from ironic watching, who have the childish gall actually to endorse and instantiate single-entendre principles. Who treat of plain old untrendy human troubles and emotions in U.S. life with reverence and conviction. Who eschew self-consciousness and hip fatigue. These anti-rebels would be outdated, of course, before they even started. Dead on the page. Too sincere. Clearly repressed. Backward, quaint, naïve, anachronistic. Maybe that'll be the point. Maybe that's why they'll be the next real rebels. Real rebels, as far as I can see, risk disapproval. The old postmodern insurgents risked the gasp and squeal: shock, disgust, outrage, censorship, accusations of socialism, anarchism, nihilism. Today's risks are different. The new rebels might be artists willing to risk the yawn, the rolled eyes, the cool smile, the nudged ribs, the parody of gifted ironists, the "Oh how banal." To risk accusations of sentimentality, melodrama. Of overcredulity. of softness. Of willingness to be suckered by a world of lurkers and starers who fear gaze and ridicule above imprisonment without law. ${ }^{13}$ 
Wallace clearly thinks that a good life is one of sincere, unironic commitment. But the nature of the commitment and its relationship to value remain unclear. Let's turn to some other thoughts about the good life to look for Wallace's own view.

\section{WALLACE ON HEDONISM}

The upshot of the previous section is that Wallace regards sincere commitment to a set of values as a necessary condition for a good human life.

What particular values might someone be sincerely committed to? For starters, whatever is valuable makes a life go well. Everyone will grant that things like food, shelter, and good books can be valuable when they are a means to some further value. But what's ultimately, noninstrumentally valuable? What is good in and of itself? Unsurprisingly, there is no agreement among philosophers, here as elsewhere. ${ }^{14}$ One perennial answer, endorsed by thinkers from Epicurus to Jeremy Bentham, is called value hedonism. The basic idea is that having pleasure is what makes life go well. ${ }^{15}$

What would Wallace make of value hedonism? He would be unequivocally hostile to one brand of hedonism, it seems. Some hedonists say that pleasure is a favorable attitude toward an experienced state of affairs. According to these theorists, what makes pleasure valuable is not the feeling or sensation itself, but our enjoyment of the sensation. It's the attitude of enjoyment that is crucial. That attitude, say these theorists, is what has value. By contrast, other hedonists think of pleasure purely as a sensation. They say that the valuable thing about pleasure is the sensation itself-immediate sensory experiences themselves are good. On this understanding of pleasure, someone may enjoy some experience of hers, but it's not her enjoyment of the experience that gives it value. 
Wallace sees pleasure-as-mere-sensation hedonism as an unacceptably narrow account of the good human life. Consider Infinite Jest, in which several characters become fixated on the film of the same title. Watching that film is so blissful that viewers can't tear themselves away, and they eventually die after ignoring all other areas of life. Wallace's case is complicated. ${ }^{16}$ Yet surely these characters, whatever else we say about them, are not flourishing human beings-even though they satisfy the requirements for flourishing set down by the version of hedonism at issue. Or consider what Wallace says in his essay about a seven-night luxury Caribbean cruise: he reflects on the "Insatiable Infant" part of himself, the part that "WANTS" felt pleasure. The "big lie" of the luxury cruise, Wallace tells us, is that this infantile part can be finally put to rest by total, perfectly delivered pampering and pleasure. That's a lie because trying to satisfy this infant is impossible- "its whole essence or dasein or whatever lies in its a priori insatiability." ${ }^{17}$

But here's a perhaps more straightforward example, drawn from Infinite Jest. Prince Q-, the Saudi Minister of Home Entertainment, organizes his life around eating the freshest available Töblerone chocolate bars in immense quantities. The prince's chocolate habit badly imbalances his diet, and he employs a medical attaché to relieve the suffering his diet causes, allowing him to continue eating. The case is amusing, in a way, because the attaché is hired not to treat the addiction but to enable the prince's absurd and unhealthy habit. ${ }^{18}$

One potential reaction to this case-one suggested by pleasureas-mere-sensation hedonism-is to wish that Prince Q- didn't need to endure such maxillofacial suffering to reach chocolaty bliss. But of course this response misses the point. What's sad here is not only the lengths the prince goes to get pleasure but the narrowness of his life. The problem is not that he doesn't have enough pleasure in life. It's that he has nothing else. His life is about the 
wrong thing, we think Wallace would say, and so any theory that implies that such a life of pleasure goes well can't be correct.

But Wallace might still seriously entertain other forms of hedonism. What the remaining views share is simple: they allow that the content of well-being is, somehow, "up to us." Hedonism says it's pleasure that matters. On this view, value is "nonobjective," in the sense that what is valuable is determined by how we feel rather than by facts independent of how we feel. ${ }^{19}$

Could Wallace endorse some version of hedonism? There's at least some evidence that he could be friendly to such a view. Following his takedown of ironism in "E Unibus Pluram," he privately expressed interest in the idea that people "construct" value. D. T. Max calls attention to a snippet from Wallace's notebook: "Hyperc[onsciousness] makes life meaningless [. . .]: but what of will to construct OWN meaning? Not the world that gives us meaning but vice versa? Dost[oevski] embodies this-Ellis, Leyner, Leavitt, Franzen, Powers-they do not. Their fictions reduce to complaints and self-pity." ${ }^{20}$

Wallace greatly admired Dostoevsky's boldness in constructing meaning. ${ }^{21}$ To construct meaning, let's say, is to produce a kind of value where once there was none. Hedonism suggests a way in which we might produce value: when someone finds pleasure in something, it becomes valuable for her, even if no one previously found pleasure in it and it was thus never valuable before.

We suspect Wallace would agree that some versions of hedonism capture something important. They avoid the ironist's error of never taking herself seriously. In fact, if people do not regard themselves as valuable-indeed, as sources of value-they couldn't care about enjoying anything in the first place. And so hedonism implies that ironism is false. That's a promising start.

Although Wallace would laud value hedonists for sticking out their necks and saying that life should be about something, he nevertheless expresses deep worries about the role of pleasure in 
a good life. Consider a series of questions from his "Joseph Frank's Dostoevsky":22

Is the real point of my life simply to undergo as little pain and as much pleasure as possible? My behavior sure seems to indicate that this is what I believe, at least a lot of the time. But isn't this kind of a selfish way to live? Forget selfish-isn't it awful lonely? ... But if I decide to decide there's a different, less selfish, less lonely point to my life, won't the reason for this decision be my desire to be less lonely, meaning to suffer less overall pain? Can the decision to be less selfish ever be anything other than a selfish decision? ${ }^{23}$

Wallace wonders here whether hedonism is avoidable as a psychological doctrine-after all, we can always describe the motivation for an action in terms of its expected utility for the actor. But the element of this passage we want to underline is Wallace's recognition that, fully bracketing the apparent selfishness involved in a life of pursuing one's desires, such a life just seems sad. Not only would we say that such a person is selfish, but we'd say that they miss something important about life.

Hedonism grants the individual a kind of license or control over the content of a good life. Yet these views lead to an impoverished account of why the chosen content is valuable. Wallace says that life thus described sounds "lonely." We surmise he means that it offers a sad description of states of affairs involving other people. On these theories, other people are no more than mere objects in the state of affairs you value. If a friend is valuable to you, why is that? Well, she's valuable because of the pleasure she brings you or the pain she helps you avoid. A friend can be no more than an instrument for your purposes, with respect to matters of value. Unsurprisingly, Wallace thinks this description of friendship seems lonely. 
Hedonists won't give up so easily. They may insist that Wallace is confused about their position-it tells us what is good for a particular human being. And surely, they'll reply, other people are only good for someone to the extent that others serve as useful objects in beneficial states of affairs. Fair enough. But Wallace suggests an explanation for any appeal of this reply.

Everything in my own immediate experience supports my deep belief that I am the absolute center of the universe, the realest, most vivid and important person in existence. We rarely think about this sort of natural, basic self-centeredness, because it's so socially repulsive, but it's pretty much the same for all of us, deep down. It is our default setting, hardwired into our boards at birth. Think about it: there is no experience you have had that you are not the absolute center of. The world as you experience it is there in front of you or behind you, to the left or right of you, on your TV, or your monitor, or whatever. Other people's thoughts and feelings have to be communicated to you somehow, but your own are so immediate, urgent, real. You get the idea. But please don't worry that I'm getting ready to preach to you about compassion or other-directedness or all the socalled "virtues." This is not a matter of virtue-it's a matter of my choosing to do the work of somehow altering or getting free of my natural, hardwired default setting which is to be deeply and literally self-centered, and to see and interpret everything through this lens of self. ${ }^{24}$

Wallace thinks that we should reject this way of thinking of the good life. It seems selfish, to be sure ${ }^{25}$ but his point is different: our own natural self-centeredness leads us to misunderstand our own good. We confuse the immediacy of our subjective experience with its importance. 
If our native viewpoint easily confuses us about what's important, what can be done? Is there another perspective that allows us to think more clearly about value? We will consider one important possibility next.

WALLACE ON NARRATIVE THEORIES OF THE GOOD LIFE Although Wallace was at least attracted to the idea that we somehow "construct" values that contribute to well-being, hedonism won't fit with his thinking. But there are other ways we might "construct" the content of the good life for ourselves. One family of views is so-called narrative theories of the good life. Galen Strawson sums up the core of these theories as follows: "a richly narrative outlook on one's life is essential to living well." ${ }^{26}$ The basic idea is that someone has a good life only if she has a narrative outlook on her life. To use ordinary terms, she must see her life as making sense as a single story in which she is the main character. Strawson's summing up leaves room for elaboration, and the details are filled in variously by different theorists. Narrative theories have enjoyed some popularity among contemporary philosophers, and prominent advocates include Christine Korsgaard, Charles Taylor, and J. David Velleman. ${ }^{27}$

All narrative theorists affirm that having a narrative is a necessary condition for a good life. We'll call this the "weak" thesis. But some theorists also endorse a more controversial thesis according to which a person simply is the thing described by a narrative. This "strong" thesis happens to imply the weak thesis, but the latter doesn't imply the former. ${ }^{28}$ We will first discuss the weak thesis before we explain how the strong thesis plays a role in one defense of narrative theories.

Narrative theories, like hedonism, allow the content of someone's good to be determined by particular features of her 
psychology. Consider how narrative theories leave value "up to us" in a sense while avoiding some pitfalls of hedonism. For one thing, the value of elements within our stories may depend on various propositional attitudes, and those are certainly not limited to the attitude of enjoyment. For another, the potential roles of persons-ourselves included-within our stories is less restrictive. On narrative theories, persons are characters just as in literature, playing far more nuanced roles than self as enjoyer-of-statesof-affairs or friend as instrument-in-bringing-about-enjoyablestates-of-affairs. Hedonism would seem to recommend analyzing all roles in those limited ways.

Here are two further advantages that narrative theories may enjoy over hedonism. First, narrative theories better capture the richness of human lives and the distinctive value of our long-term projects. For instance, we care about being loving parents, faithful friends, about the success of our work, and so on. Narrative theories allow for a clear divide between these important projects and ephemeral ones. How well our lives go depends on those significant projects, not on whether we clip our fingernails perfectly. Life goes no worse for us, not one bit, when we don't clip our nails right. But, arguably, hedonism must count a poor nail-clipping job as relevant to how our lives go, insofar as such events have some slight impact on our enjoyment. Second, narratives can focus attention in morally significant ways. A person may regard being a faithful friend as an element of her own good, and think that this part of her story is more important than whether she always gets her way in small or trivial matters. So, narratives can redirect our thoughts away from the flow of our first-person experience, precisely as Wallace counsels in This Is Water. Stories can guard us against being enslaved by our immediate inclinations.

Parts of This Is Water seem to suggest that Wallace may find something to like about narrative theories. One commentator on Wallace's ethical thought has argued that Wallace appreciated "the 
importance of the direction of attention, and the terms in which we choose to conceive of situations, in our moral lives." ${ }^{29}$ Our petty frustration in rush-hour traffic or in a supermarket checkout line may be managed, Wallace thinks, with help from imaginative storytelling. Telling stories about the meaning of commonplace situations may help us overcome our self-centered perspective: we need a narrative that will sympathetically reveal to us the reality of others' lives. ${ }^{30}$

So, narratives refocus the subject of our attention and capture the complexity of our lives and projects. But are stories related to value, according to Wallace? And if so, how? Does he accept some version of narrative theory? Do stories help us lead good lives because a life can't go well without a story?

Wallace seems to deny that well-being requires a narrative outlook. ${ }^{31}$ The main question to ask is this: is seeing your life as a story an essential part of a good life? Narrative theorists say "yes," but Wallace answers "no," and we can see this by surveying important passages from his fiction. So, Wallace rejects the weak thesis.

Briefly, before we work through several examples from his fiction, it's worth noting a general theme raised by the examples: narratives increase self-awareness and so prompt us to ask ourselves questions that tend to undermine well-being. Here are the kinds of questions we have in mind: Am I living up to my own idea of myself? Does my story have the virtues of good stories? Is it original, unique? Are there no unnecessary or dull sections? Is this a story other people will like? Are they interested? Does my concern with these questions really reveal that, down deep, I'm committed to this narrative for the wrong reasons to begin with? It's one thing to lean back from the steady flow of the first-person perspective, which Wallace recommends, and another altogether to become hyper-self-aware in that way. Someone might end up feeling cramped or even tyrannized by thinking about one's narrative. Indeed, Wallace more than once 
reveals how asking these sorts of questions can undermine a person's well-being.

Turn now to some examples. Wallace holds that when someone thinks of her life in terms of her narrative, far from helping her lead a good life, it may make her feel like she has fallen short. She is driven to ask the kind of questions noted earlier about her motivation in choosing her commitments in the first place. The result is what Wallace calls the fraudulence paradox:

The fraudulence paradox was that the more time and effort you put into trying to appear impressive or attractive to other people, the less impressive or attractive you felt inside-you were a fraud. And the more of a fraud you felt like, the harder you tried to convey an impressive or likable image of yourself so that other people wouldn't find out what a hollow, fraudulent person you really were. ${ }^{32}$

This way of managing appearances leaves the narrator "frightened, lonely, alienated, etc." The problem here is with one's selfperception. Thinking of one's life from the point of view of a narrative makes one self-conscious and, in turn, interferes with living well.

In "The Depressed Person," Wallace offered a distressing look at how self-awareness can literally ruin a life. The story's main character is clinically depressed and fully aware of her condition. Her deep concern is that her depression prevents her from being anything more than a parasite on her friends-her "support system." She'd like to realize her "capacity for basic human empathy and compassion and caring." ${ }^{33}$ But how can she do this when she is focused entirely on herself? Paradoxically, concern for her life's narrative fixes her gaze there. In the story, in the wake of her therapist's suicide, the depressed person realizes that she is herself 
inappropriately self-centered. She expresses concerns about her self-centeredness to a terminally ill friend:

The depressed person shared that the most frightening implication of this (i.e., of the fact that, even when she centered and looked deep within herself, she felt she could locate no real feelings for the therapist as an autonomously valid human being) appeared to be that all her agonized pain and despair since the therapist's suicide had in fact been all and only for herself, i.e. for her loss, her abandonment, her grief, her trauma and pain and primal affective survival. And, the depressed person shared that she was taking the additional risk of revealing, even more frightening, that this shatteringly terrifying set of realizations, instead now of awakening in her any feelings of compassion, empathy, and other-directed grief for the therapist as a person, had-and here the depressed person waited patiently for an episode of retching in the especially available trusted friend to pass so that she could take the risk of sharing this with herthat these shatteringly frightening realizations had seemed, terrifyingly, merely to have brought up and created still more and further feelings in the depressed person about herself. At this point in the sharing, the depressed person took a time-out to solemnly swear to her long-distance, gravely ill, frequently retching but still caring and intimate friend that there was no toxic or pathetically manipulative self-excoriation here in what she (i.e., the depressed person) was reaching out and opening up and confessing, only profound and unprecedented fear: the depressed person was frightened for herself ... she told the supportive friend with the neuroblastoma. She was asking sincerely, the depressed person said, honestly, desperately: what kind of person could seem to feel nothing-"nothing," she emphasizedfor anyone but herself? . . . What words and terms might be applied to describe and assess such a solipsistic, self-consumed, 
endless emotional vacuum and sponge as she now appeared to herself to be? How was she to decide and describe-even to herself, looking inward and facing herself-what all she'd so painfully learned said about her? ${ }^{34}$

What this passage reveals-excruciatingly-is that the depressed person has a serious problem not only with depression, but with narcissism. ${ }^{35}$ The depressed person thinks that living a good life, for her, depends in part on whether she meets her description of a compassionate friend. Wallace helps us see here that narratives don't always get us "out of our own heads" in the right way. Instead of thinking of her terminally ill friend, the depressed person wonders whether she's doing enough to qualify as compassionate. Wallace seems to use compassion to show that concern for narrative interferes with the realization of other-regarding virtue. Because the depressed person's attention is focused on her narrative and whether she's living up to it, her efforts to be compassionate leave her feeling even worse about herself. Any compassionate act pushes her even further from realizing her narrative because she'll have acted to make herself qualify as compassionate, not out of genuine concern for another. Her narrative perspective actually makes it impossible for her to attain her ideal. The narrative makes her feel like a fraud and a failure.

Wallace's fiction also highlights a related problem: we tend to overvalue uniqueness or specialness in narratives, and this leaves us feeling inauthentic. One popular assumption in our culture is that an authentic and valuable life must be characterized by special, unusual, or even extreme commitments. We're relentlessly subjected to the message that everyone is different, and so it seems reasonable for us to conclude that we're living defective lives if we lack eccentric values. But this is to confuse uniqueness with authenticity. The main character in Wallace's "Good Old Neon," Neal, makes precisely that mistake. 
I spent all my time trying to get [my peers] to think I was dry and jaded as well. ... Putting in all this time and energy to create a certain impression and get approval or acceptance that then I felt nothing about because it didn't have anything to do with who I really was inside, and I was disgusted with myself for always being such a fraud, but I couldn't seem to help it. Here are some of the various things I tried: EST, riding a ten-speed to Nova Scotia and back, hypnosis, cocaine, sacro-cervical chiropractic, joining a charismatic church, jogging, pro bono work for the Ad Council, meditation classes, the Masons, analysis, the Landmark Forum, the Course in Miracles, a right-brain drawing workshop, celibacy, collecting and restoring vintage Corvettes, and trying to sleep with a different girl every night for two straight months. ${ }^{36}$

Wallace's suggestion is that Neal felt the need to try out these commitments because they cast him in a certain light for the audience of his narrative. His commitments presented him as kind, cynical and world-weary, spiritually deep, emotionally damaged in some interesting way, or some other mix of special traits. There are at least two clear problems with trying to construct a life narrative that is unique. First, as Wallace later has the narrator remark, "human beings are all pretty much identical in terms of our hardwiring." ${ }^{37}$ It's difficult to come up with commitments that make one stand out as a truly unique person. Anything that one person finds appealing will probably also appeal to others. Second, and more fundamentally, the uniqueness of a commitment is usually unrelated to its value. A painting or a cantata doesn't become less beautiful as more people enjoy it. The same is true of the narrative elements that might constitute a good life. The things someone cares about might distinguish her from others, but that's not enough, by itself anyway, to make them valuable for her.

Both points find clear expression at the conclusion of "Good Old Neon." In the end, Neal begins to think that the reason he felt like 
such a fraud, yet was hopeless to change, was that he was unable to love. He couldn't let himself be happy because he couldn't even love himself. Tragically, he applied the criteria for a good narrative even to his diagnosis of why his life wasn't going well, and his explanation proved insufficiently unique.

I happened on part of an old Cheers episode from late in the series' run where the analyst character, Frasier ..., and Lilith, his fiancée and also an analyst, are just entering the stage set of the underground tavern, and Frasier is asking her how her workday at her office went, and Lilith says, "If I have one more yuppie come in and start whining to me about how he can't love, I'm going to throw up." This line got a huge laugh from the show's studio audience, which indicated that they-and so by demographic extension the whole national audience at home as wellrecognized what a cliché and melodramatic type of complaint the inability-to-love concept was.... The flash of realizing all this at the very same time that the huge audience-laugh showed that nearly everybody in the United States had probably already seen through the complaint's inauthenticity as long ago as whenever the episode had originally run. . . It more or less destroyed me, that's the only way I can describe it, as if whatever hope of any way out of the trap I'd made for myself had been blasted out of midair or laughed off the stage, as if I were one of those stock comic characters who is always both the butt of the joke and the only person not to get the joke. ${ }^{38}$

The sadness here is palpable. Neal has assumed a good life needs to be unique, though here he finds this can't be true for his own life: he's like many other people. But it shouldn't be surprising that many people have, or think they have, the same problem. And of course the fact that so many people are similarly afflicted does not mean it's insignificant or that they are inauthentic. 
The wide distribution of the inability-to-love problem certainly doesn't reveal that someone with this problem would be more authentic were it his alone. Even if the distinctiveness of a problem happened to make some person's story more interesting to an audience, that would have nothing to do with whether his life goes well. Wallace thinks that our culture overvalues uniqueness, and surely he's right.

So far, we have noted examples from Wallace's fiction where fidelity to a narrative undermines well-being. The examples are crucial for understanding Wallace's attitude toward narrative theories.

These cases are counterexamples to the weak thesis-the claim that well-being requires a narrative outlook on life. To illustrate why, consider the narrator in "Good Old Neon." Tear away his life's circumstances from his tangled web of narrative. Here are the facts: Neal has a family who loves him, a knack for interesting work, time to devote to volunteering and hobbies, and so forth. This guy's life appears on track to go well. He's blessed. But notice what happens once we drop him back inside the narrative structure he has built up. There things start to fall apart for him-the narrativity badly screws him up. Because of his story about his own fraudulence and his inability to love, anything valuable in his life now fails to make him better off. The narrative is a kind of poison.

Wallace wants us to see that the narrator's fidelity to his narrative ruins his life. But we must not ignore a corollary: his life would have been a good one without the narrative. From this it seems to follow that that narrative is not required for a good life. Wallace's example of narrative undermining well-being casts doubt on the weak thesis. The important question, again: is seeing life as a story an essential part of a good life? Wallace sure seems to think there are cases where that's not so. The same point could be made with the other examples as well, but let's proceed. 
Although narrative theorists will no doubt agree that narratives can undermine well-being, they may insist that's because the narratives are improperly used, not because well-being doesn't require a narrative outlook on life. In light of Wallace's examples, then, narrative theorists might try to explain why narratives sometimes undermine the good life.

A first thought is that Wallace's examples underline problems people tend to encounter by using narratives as action-guiding plans. But using narratives in that way is a mistake. Narratives are not for action guidance-they are for evaluation of a life's goodness. This means that a theory of the good life may be "self-effacing"that is, the good might sometimes be better promoted by ignoring the theory itself-but, for all that, the theory might be true. Many philosophers have been satisfied with self-effacing theories of the good. Though we strongly suspect that Wallace would regard this as undesirable, we'll wait for the conclusion to say more. For now, let's assume that this line is closed off for narrative theorists.

Here's another thought. Defenders of narratives might try to avoid the problems Wallace noted by revising the weak thesis. They might say that narratives undermine well-being in difficult cultural conditions and insist that narratives must be endorsed by someone free of cultural defects. Who? A suitably idealized agent-that is, a fully informed or perfectly rational person. In other words, the narrative theorists would claim that not just any old narrative will do: the weak thesis must be supplemented with more demanding conditions for what sort of narrative can make a life good. Then the weak thesis is transformed as follows: well-being requires a narrative outlook on life that's also endorsed by a suitably idealized agent. Plausibly, an idealized agent wouldn't consider features like uniqueness, for instance, in developing a narrative. (For instance, an idealized agent wouldn't experience Neal's embarrassment and self-loathing in response to the joke on Cheers because those reactions are based on a mistaken concern 
for uniqueness.) Thus, sophisticated narrative theories can avoid the problems arising from culture that Wallace points out.

Some of Wallace's criticisms are indeed leveled at unhealthy uses of narratives that result from nonideal cultural conditions. But he also raises a deeper point, mentioned in passing above, that tells against the idea that a narrative is necessary for well-being. To judge one's life in terms of narrative success is to adopt a certain perspective. This perspective involves thinking of oneself as a character in a story, and evaluating that character in terms of her or his compliance with the story's demands. If this sounds alienating, there's a good reason. It is. In fact, this very change in perspective gives rise to the paradox of fraudulence that Wallace describes-"that the more time and effort you put into trying to appear impressive or attractive to [an audience], the less impressive or attractive you felt inside." ${ }^{39}$ The narrator in "Good Old Neon" describes the attitude to oneself that the narrative perspective calls for:

In the dream, I was in the town commons in Aurora . . . and what I'm doing in the dream is sculpting an enormous marble or granite statue of myself . . . and when the statue's finally done I put it up on a big bandstand or platform and spend all my time polishing it and keeping birds from sitting on it or doing their business on it, and cleaning up litter and keeping the grass neat all around the bandstand. And in the dream my whole life flashes by like that, the sun and moon go back and forth across the sky like windshield wipers over and over, and I never seem to sleep or eat or take a shower ... meaning I'm condemned to a whole life of being nothing but a sort of custodian to the statue..$^{40}$

Narrative theories turn us into custodians of ideal selves. But that isn't what being a human being is about, Wallace thinks. After finally being persuaded by the mocking laughter of the Cheers 
studio audience that his fraudulence was inescapable, the narrator, Neal, offers a final diagnosis for his life's failure: "my own basic problem was that at an early age I'd somehow chosen to cast my lot with my life's drama's supposed audience instead of with the drama itself." ${ }^{41}$ In requiring us to side with the audience of our narrative and not with ourselves, narrative theories alienate us from who we are and what's good for us. We should experience our lives as participants instead of as spectators.

Some narrative theorists may have an interesting reply to this concern. Let's suppose that our narratives don't merely describe what is good for us. They constitute us. This is the stronger understanding of narrative theory mentioned already-a person is identical with her narrative. Christine Korsgaard has defended this idea and writes: "We construct ourselves from our choices, from our actions, from the reasons that we legislate." ${ }^{42}$ So, narratives do more than set the parameters for a good life. Narratives also make particular persons who they are. Crucially, if that's so, there can be no complaint about alienation. If you are your narrative, there's no way your narrative can alienate you from yourself. There's no you without it.

The strong thesis features a subtle and complicated understanding of the self. We're not ultimately sure how Wallace would engage with the view, but there's one passage in his writings that may serve as a kind of response to it.

Perhaps Wallace would reject this view of the self's constitution because it misconstrues what a person is. To see what we mean, compare the following two passages. Witness Korsgaard on the value of a life in which one violates the commitments of one's narrative:

It is the conceptions of ourselves that are most important to us that give rise to unconditional obligations. For to violate them is to lose your integrity and so your identity, and to no longer be 
who you are. That is, it is to no longer be able to think of yourself under the description under which you value yourself and find your life to be worth living and your actions to be worth undertaking. It is to be for all practical purposes dead or worse than dead..$^{43}$

Compare Korsgaard's words to a striking passage from "Good old Neon." Wallace is here speaking to the narrator about the narrator's decision to commit suicide, his decision to escape the essential fraudulence that comes with failing to achieve the goals of his various narratives (or even to settle on a single narrative). Wallace addresses the postmortem Neal:

You already know the difference between the size and speed of everything that flashes through you and the tiny inadequate bit of it all you can ever let anyone know. As though inside you is this enormous room full of what seems like everything in the whole universe at one time or another and yet the only parts that get out have to somehow squeeze out through one of those tiny keyholes you see under the knob in older doors. As if we are all trying to see each other through these tiny keyholes. ... What exactly do you think you are? The millions and trillions of thoughts, memories, juxtapositions ... that flash through your head and disappear? Some sum or remainder of these? Your history? ... The truth is you've already heard this. That this is what it's like. That it's what makes room for the universes inside you, all the endless inbent fractals of connection and symphonies of different voices, the infinities you can never show another soul. And you think it makes you a fraud, the tiny fraction anyone else ever sees? Of course you're a fraud, of course what people see is never you. And of course you know this, and of course you try to manage what part they see if you know it's only a part. Who wouldn't? It's called free will, Sherlock. But at the same time it's 
why it feels so good to break down and cry in front of others, or to laugh, or speak in tongues, or chant in Bengali-it's not English anymore, it's not getting squeezed through any hole. So cry all you want, I won't tell anybody. But it wouldn't have made you a fraud to change your mind. It would be sad to do it because you think you somehow have to. ${ }^{44}$

Here's the philosophical point: we are not merely our narratives, Wallace would say, because no narrative-perhaps nothing ever explicitly thought in words-can capture who we are. Although narratives can usefully express to others and to ourselves what we care about, they are never who we are. Selves are ineffable. ${ }^{45}$

Korsgaard tells us that people who don't live up to their narratives haven't merely let themselves down-they have chosen a life that amounts to being "dead or worse than dead." Neal tells himself a story according to which he's a fraud, and thinks suicide is his only nonfraudulent option. Wallace appreciates the sadness in this-killing yourself for the sake of your narrative. Which passage, Korsgaard's or Wallace's, sounds more humane?

\section{CONCLUSION}

Wallace reflected on human well-being through his fiction and he offered real insights. Here are three. He contends, against the ironist, that our lives should be about something, and that we should not be embarrassed to say so and sincerely mean it. He argues compellingly that a life need not be unique or unusual to be valuable. And he offers reasons to reject the idea that wellbeing comes solely from pleasure.

Our discussion has been limited to theories on which people construct value, rather than discover it, because of Wallace's apparent preference for such views. But what would he think of 
so-called objective list theories of the good life? Those theories say that certain things-say, relationships and attaining significant knowledge-make our lives go well independently of our thoughts or preferences about them. On the one hand, Wallace might think that these views are guilty of the moralizing he means to avoid. ${ }^{46}$ On the other hand, recall Wallace's admiration for Dostoevsky's courage in sticking his neck out and creating meaning. ${ }^{47}$ So, we wonder: doesn't it require even greater courage to say that values are really out there, no matter what anyone thinks or feels, than it does to say they exist as a product of our constructive activity? We don't know how Wallace comes down on this issue. Perhaps he'd take an intermediate view, on which we construct value without always realizing it, and we gradually discover it within ourselves, often finding that it's at odds with our more conscious selfconceptions. Perhaps value is one part of "the universes inside you" that's ineffable, inexpressible.

We find in Wallace's writing more than piecemeal criticism of other views and a glimpse of bits and pieces of his own. We also find a humane recommendation about how to approach reflection on the good life. It's a sort of Wittgensteinian methodology, for lack of a better term. Wallace's interest in Wittgenstein has been well documented. ${ }^{48}$ Wittgenstein famously remarked in Philosophical Investigations: "Philosophy is a battle against the bewitchment of our intelligence by means of language." ${ }^{49}$ Wallace sees this as a dictum about the point of thinking and about the role of theories in thinking well. Thinking is supposed to solve problems. Thinking about what makes your life go well should not make you worse off. ${ }^{50}$

But some theories do precisely that. If we regard some version of narrative theory as action guiding-if we treat it as a practical guide that gives us reasons to act-then our lives will may go poorly, even by that theory's lights. As Wallace shows, concern about how one's life appears to an audience interferes with living a good life. 
Leading a good life calls for a level of involvement with the action that's precluded by too much self-awareness. Some theorists have said that their views are self-effacing, as we noted above. Their theories set out standards for evaluating lives, not guides for how to live. If we look to such theories to provide motives for acting, our lives go poorly.

One standard complaint with particular moral theories is that they're self-effacing. Wallace sees the problem as being more widespread-it's endemic to theories of the good life. The ingredients for human well-being are too subtle to be represented in a theory or, indeed, in language. Attempts to theorize about value result in partial and distorted vision. An important metaphor from "Good Old Neon" is instructive on Wallace's view, we think:

The ground fog tends to get more intense by the second until it seems that the whole world is just what's in your headlights' reach. High beams don't work in fog, they only make things worse. You can go ahead and try them but you'll see what happens, all they do is light up the fog so it seems even denser. That's kind of a minor paradox, that sometimes you can actually see farther with low beams than high. ${ }^{51}$

All of us sometimes get confused about what would be good for us, about what matters, or about what matters most. Theories refocus our attention and offer answers. Sometimes, we need a helping hand: our natural inclinations are imperfect guides to what matters in life. But following theories is risky. Theories redescribe values so they'll fit within theories-or, sometimes worse, theories explain particular values away entirely. They turn simple matters, ones we could see through perfectly fine, into intellectual perplexities. We can figure out some things-like the value of relationships or the proper expression of compassion-better without theories. None of this means that theories of the good life are bad 
or useless. They just need to be kept in their place. We need to recognize what such theories are for.

So what are they for? One proposal, borrowed from David Schmidtz, is that theories are best understood as maps: "A map is not itself the reality," writes Schmidtz. "It is at best a serviceable representation. Moral theories likewise are more or less serviceable representations of a terrain. They cannot be more than that." ${ }^{2}$ Different problems call for different maps, and we know that a map won't tell us everything. It shouldn't, either. A map that details everything about its subject is useless, in part because we don't need the map to represent everything, and we can't use everything anyhow. Maps are only helpful when we need to know the way. They sometimes work as stand-ins for practical wisdom about the local terrain. But they are never good when treated as full-scale reproductions of the world.

With these points in mind, notice that Wallace can answer the claim that a theory might be true but self-effacing: it's not much of a theory if it can't tell us how to go somewhere we need to go. Determining whether or not a life was good, after the fact, is usually not a genuine human problem. A theory that could offer us the correct answer to that question would be an intellectual achievement, to be sure, but Wallace sees it as little else. The point of thinking is to solve problems that matter to us, not to be clever for cleverness's sake.

Kurt Baier once complained that "moral talk is often rather repugnant. Leveling moral accusations, expressing moral indignation, passing moral judgment, allotting the blame, administering moral reproof, justifying oneself, and, above all, moralizing-who can enjoy such talk?"53 When we talk about or apply a moral view, it might seem judgmental or cruel to others. But there is another way a moral theory might be cruel. Wallace recognizes that theories of the good life, when taken to be more than limited sketches of reality, tend to result in our being judgmental or cruel 
to ourselves. Our pursuit of good in life is about something else entirely, thinks Wallace:

If you can think of times in your life that you've treated people with extraordinary decency and love, and pure uninterested concern, just because they were valuable as human beings. The ability to do that with ourselves. To treat ourselves the way we would treat a really good, precious friend. Or a tiny child of ours that we absolutely loved more than life itself. And I think it's probably possible to achieve that. I think part of the job we're here for is to learn how to do this. ${ }^{54}$

\section{NOTES}

This paper is the product of full and equal collaboration between its authors. The authors wish to express their gratitude to Andrew Bailey, Thomas Crisp, William Dyer, Chris Freiman, Stephen Grimm, David Schmidtz, David Storey, and Benjamin Wilson for comments on an earlier version of this essay.

1. David Foster Wallace, interview by Larry McCaffery, "An Interview with David Foster Wallace," Review of Contemporary Fiction 13, no. 2 (summer 1993): 131.

2. David Foster Wallace, "E Unibus Pluram: Television and U.S. Fiction," in A Supposedly Fun Thing I'll Never Do Again (New York: Little, Brown and Company, 1997), 67.

3. See Stephen J. Burn, ed., Conversations with David Foster Wallace (Jackson: University Press of Mississippi, 2012), 80.

4. McCaffery, "An Interview," 146.

5. David Foster Wallace, Infinite Jest (New York: Little, Brown and Company, 1996), 694.

6. Wallace, Infinite Jest, 694-695.

7. Wallace, "E Unibus Pluram," 67.

8. Wallace was certainly aware of Rorty-one of Rorty's books is the namesake of Wallace's story "Philosophy and the Mirror of Nature." We wonder: had Wallace read Rorty's work on irony? If so, was he influenced by it? 
9. Richard Rorty, Contingency, Irony, and Solidarity (Cambridge: Cambridge University Press, 1989), 73.

10. Ibid.

11. Ibid., 87.

12. Ibid., 73-74.

13. Wallace, "E Unibus Pluram," 81-82. For more on similar themes, see Wallace's essay "Robert Frank's Dostoevsky," in Consider the Lobster and Other Essays (New York: Little, Brown and Company, 2005). Wallace regards Dostoevsky as a writer who exemplified the "brave" unironic commitment to "moral/spiritual values."

14. See Shelly Kagan, Normative Ethics (Boulder, Colo.: Westview, 1998), 29-41, for a brief review of accounts of well-being. See also Russ ShaferLandau, The Fundamentals of Ethics, 2nd ed. (New York: Oxford University Press, 2011), chaps. 1-4, for discussion of hedonism and the desire-satisfaction theory.

15. We'll only consider Wallace's reactions to hedonism here, but we think that Wallace would take a similar stance toward a related "nonobjective" view, the desire-satisfaction theory of well-being, according to which having one's desires satisfied, getting what one wants, makes life go well, whether it's pleasurable or not.

16. It's at least superficially like Robert Nozick's “experience machine." See his Anarchy, State, and Utopia (New York: Basic Books, 1974), 42-45.

17. Wallace, "A Supposedly Fun Thing I'll Never Do Again," in A Supposedly Fun Thing, 316-317.

18. "The medical attachés particular expertise is the maxillofacial consequences of imbalances in intestinal flora. Prince Q- (as would anyone who refuses to eat pretty much anything but Töblerone) suffers chronically from Candida albicans, with attendant susceptibilities to monilial sinusitis and thrush, the yeasty sores and sinal impactions of which require almost daily drainage" (Infinite Jest, 33). Stories like the prince's are not so uncommon in real life. Consider one such story from the history of rock and roll. When Slash, lead guitarist of Guns N' Roses, began regularly passing out in public because of his alcohol and drug abuse, he didn't get help for addiction: he hired a handler to ensure that he didn't get arrested.

19. This view is highly similar to the desire-satisfaction accounts of wellbeing mentioned in note 15 , above.

20. D. T. Max, Every Love Story Is a Ghost Story (New York: Penguin, 2013), 209. 
21. The passage from Wallace's notebook continues with praise for the Russian writer: "Dostoevski has BALLS."

22. I.e., "really urgent stuff inside asterisks as part of some multivalent defamiliarization-flourish” (Wallace, “Joseph Frank's Dostoevsky," 271).

23. Ibid., 261-262.

24. David Foster Wallace, This Is Water (New York: Little, Brown and Company, 2009), 36-44. Wallace is eager to distance himself from morality and moralizing in This Is Water: "None of this is about morality, or religion, or dogma, or big fancy questions of life after death" (128). But we think he's interested here in the good life. Daniel Turnbull offers helpful suggestions to explain Wallace's reluctance to call his purposes "moral," even though they are decidedly moral. See Daniel Turnbull, "This Is Water and the Ethics of Attention: Wallace, Murdoch, and Nussbaum," in Consider David Foster Wallace: Critical Essays, ed. David Hering (Los Angeles: Slide Show Media Group Press, 2010), 210-211.

25. Even if a charge of selfishness reveals the moral wrongness of pursuing our own good at a cost to others, it doesn't show that these accounts of the good are incoherent. After all, it may be that our own good conflicts with the good of others.

26. Galen Strawson, "Narrativity and Non-Narrativity," Wiley Interdisciplinary Reviews: Cognitive Science 1, no. 6 (2010): 775. Strawson's paper offers a helpful overview of narrative theories, along with some criticisms.

27. Here is Charles Taylor: "Because we cannot but orient ourselves to the good, and thus determine our place relative to it and hence determine the direction of our lives, we must inescapably understand our lives in narrative form, as a 'quest.' But one could perhaps start from another point: because we have to determine our place in relation to the good, therefore we cannot be without an orientation to it, and hence must see our life in story. From whichever direction, I see these conditions as connected facets of the same reality, inescapable structural requirements of human agency" (Charles Taylor, Sources of the Self: The Making of the Modern Identity [Cambridge, Mass.: Harvard University Press, 1989], 51-52).

28. That's because if persons are constituted by narratives, as the strong thesis holds, then there is no life to go well or ill minus a narrative. In other words, someone can have a good life only if she has a narrative because she has a life only if she has a narrative. But the weak thesis 
could be true even if the strong one is false: even if persons are not constituted by narratives, well-being may still require a narrative.

29. Turnbull, "This Is Water and the Ethics of Attention," 209.

30. Wallace, This Is Water, 77-93.

31. We suspect that Wallace was attracted to narrative theories early in his literary career. For example, his first novel was inspired in part by a girlfriend's remark that she "would rather be a character in a novel than a real person," and Wallace "got to wondering just what the difference was" (Max, Every Love Story Is a Ghost Story, 44). (Of course, if there is no difference, the strong thesis is true.) In a 1988 essay, he remarked: "Each drama has a hero. He's purposely designed so that we by our nature 'identify' with him. At present this is still not hard to get us to do, for we still tend to think of our own lives this way: we're each the hero of our own drama, others around us remanded to supporting roles or (increasingly) audience status" (David Foster Wallace, "Fictional Futures and the Conspicuously Young," in Both Flesh and Not [New York: Little, Brown, 2012], 50). Though Wallace never says that we should regard our lives as stories or that we must do so to have good lives, he may have thought something like that. Later, as we will see, Wallace came to think that by understanding your life as a kind of narrative, you demote yourself to “audience status," too.

32. David Foster Wallace, "Good Old Neon," in Oblivion: Stories (New York: Little, Brown and Company, 2004), 147.

33. David Foster Wallace, "The Depressed Person," in Brief Interviews with Hideous Men (New York, Little, Brown and Company, 1999), 57.

34. Ibid., 56-58.

35. That isn't to say that the depressed person's narcissism and depression are unrelated. Wallace briefly discussed the story in an interview: "This is the most painful story I have ever written. It's about the narcissism which accompanies depression. The main figure is marked by my own character traits. I actually lost friends while I was working on this story-I was ugly and unhappy and just yelled at everyone. The terrible thing about depression is that it's such a self-absorbed illnessDostoyevsky shows this well in his Notes from the Underground. Depression is painful-you're devoured by yourself; the worse the depression is, the more you think only of yourself and the more alien and repellent you appear to others." The full interview, in German, is available here: 
http://www.zeit.de/2007/05/L-Interview. Thanks to Robin Litscher for the English translation.

36. Wallace, "Good Old Neon," 142-143.

37. Ibid., 174.

38. Ibid., 168-169.

39. Ibid., 147.

40. Ibid., 160-161.

41. Ibid., 176.

42. Christine Korsgaard, Self-Constitution: Agency, Identity, and Integrity (New York: Oxford University Press, 2009), 207.

43. Christine Korsgaard, Sources of Normativity (New York: Cambridge University Press, 1996), 102.

44. Wallace, "Good Old Neon," 178-180.

45. Here's a sobering thought or two. All of us are sometimes wrong about ourselves in important ways. We misinterpret our own motives, misunderstand the things that matter to us, and misread our relationships with others. Our lives are often improved when we see these mistakes and try to fix them. But the narrative perspective makes such changes harder than they might otherwise be. It encourages us to ignore or explain away "data” about ourselves that doesn't fit with our current self-conception. It makes facing up to these conflicts into a kind of failure to live up to our story. Narrativity leads us to find linearity in life where it does not always exist. This is no way to understand who we are.

46. See note 24 .

47. See the section "Wallace on Hedonism," above.

48. D. T. Max, Every Love Story Is a Ghost Story, 44-47. See also Ira B. Nadel, "Consider the Footnote," in The Legacy of David Foster Wallace, ed. Samuel Cohen and Lee Konstantinou (Iowa City: University of Iowa Press, 2012), 222-223.

49. Ludwig Wittgenstein, Philosophical Investigations, 3rd ed., trans. G. E. M. Anscombe (Malden, Mass.: Blackwell, 2001), 40, §109.

50. The idea here is not that you should accept the theory that yields the most glowing assessment of your own life. Rather, it's that the act of thinking should not make you worse off. To be sure, thinking might well lead you to understand that your life goes badly. That's importantly different than thinking actually causing your life to go worse.

51. Wallace, “Good Old Neon," 177. 
52. David Schmidtz, Elements of Justice (New York: Cambridge University Press, 2006), 22. We see some parallels between Wallace's view and those Schmidtz develops in his essay "The Meanings of Life," in Robert Nozick, ed. D. Schmidtz (New York: Cambridge University Press, 2002).

53. Kurt Baier, The Moral Point of View: A Rationalist Basis of Ethics, abridged ed. (New York: McGraw-Hill College, 1965), 3.

54. David Foster Wallace, interview by David Lipsky, in Although of Course You End Up Becoming Yourself: A Road Trip with David Foster Wallace (New York: Broadway, 2010), 292-293. 


\section{FREEDOM}

ANI) THE SELF

ESSAYS ON THE PHILOSOPHY OF

DAVID FOSTER WALLACE

Edited by Steven M. Cahn and Maureen Eckert 
Columbia University Press

Publishers Since 1893

New York Chichester, West Sussex

cup.columbia.edu

Copyright (c) 2015 Columbia University Press

All rights reserved

Library of Congress Cataloging-in-Publication Data

Freedom and the self : essays on the philosophy of David Foster Wallace / edited by Steven M. Cahn and Maureen Eckert.

Pages $\mathrm{cm}$

Includes bibliographical references and index.

ISBN 978-0-231-16152-7 (cloth : alk. paper) - ISBN 978-0-231-16153-4

(pbk. : alk. paper) - ISBN 978-0-231-53916-6 (e-book)

1. Wallace, David Foster. 2. Fate and fatalism. 3. Taylor, Richard, 1919-2003. 4. Semantics. I. Cahn, Steven M., editor.

BJ1461.F77 2015

191-dc23

Columbia University Press books are printed on permanent and durable acid-free paper.

This book is printed on paper with recycled content.

Printed in the United States of America

c 10987654321

p 10987654321

Cover images: Shutterstock

Cover design: Marc Cohen

References to websites (URLs) were accurate at the time of writing. Neither the author nor Columbia University Press is responsible for URLs that may have expired or changed since the manuscript was prepared. 